\title{
METHODS OF ESTIMATION OF HUMAN CAPITAL'S VALUE IN LABOR-INTENSIVE INDUSTRIES: A STUDY ON THE EXAMPLE OF THE PRIMORSKAYA AGRICULTURAL TRADE COMPANY, RUSSIA
}

\author{
Krasova E.V. ${ }^{*}$, Candidate of Economic Sciences \\ Vladivostok State University of Economics and Service, Vladivostok, Russia \\ Ma Yingxin, PhD, Research Associate \\ Dezhou University, Dezhou, Shandong Province, China \\ *E-mail: elena krasova@rambler.ru
}

\begin{abstract}
Estimation of human capital's value now is one of the most popular and widely discussed directions of research in Russian science at any level. This direction has great theoretical and practical significance. Both scientists and practical specialists are interested in the quantitative and qualitative characteristics of human capital in order to effectively use labor resources in economic activity. The main scientific and practical problem of the article is the absence of an exclusive method for estimating the value of human capital in enterprises and the weak approbation of these methods in practice. The purpose of the article is to review the existing methods for estimating the human capital's value in labor-intensive industries and to test some methods on the example of one of the Far Eastern enterprises - the Primorskaya Agricultural Trade Company, Ltd, located in Vladivostok, Russia. The methodological basis of the study is the theses of the modern theory of production and costs, the concept of human capital, as well as the traditional financial analysis of economic activities of enterprises. The authors justify the urgency of estimating the human capital's value of enterprises, choose the most acceptable methods for calculating the human capital's value, and test their choice on the example of the Primorskaya Agricultural Trade Co., Ltd. Among the selected methods for practical calculation is the cost method, the income method by V. Allaverdyan and income method by G.N. Tuguskina. After the calculations, the authors conclude that the income method gives the greatest value of human capital's value of the enterprise, because it includes a significant internal (professional and educational) potential of workers.
\end{abstract}

\section{KEY WORDS}

Human capital, enterprise, labor-intensive industries, cost method, income method, labor potential, human resources.

The importance of research of issues related to evaluation of human capital is due to significant role that labor resources and human capital play in modern economic life and economic development. In modern economic theory human capital is considered as a stock of knowledge, skills and abilities that every person has and can use in production process and consumer purposes [1]. The most important trend in development of modern world economy is the steady growth of investment to preservation and reproduction of human capital. Since the 1960s, the positive dynamics of investment in education, healthcare, capitalization of knowledge and skills has become the basis for sustainable development of post-industrial economies in developed countries.

Following data show the significant changes in structure of the world productive forces: in the XVIII century, the share of human capital was estimated at $10 \%$ in the total volume of aggregate capital; at the beginning of the XX century - already $33 \%$, in the second half of the $X X$ century it became more than the share of physical capital, increased by the end of the XX century to $67-69 \%$ (in the USA up to $74-76 \%$ ) and increased to $80 \%$ at the beginning of the $\mathrm{XXI}$ century [2]. 
Development of the concept of human capital both abroad and in Russia has generated a large number of scientific researches in the field of assessing its value at different levels - in the national economy, in region and, naturally, in enterprises and organizations. In modern science, special attention is paid to practical aspects of assessing the value of human capital, and this fact determines the importance and relevance of this study. Estimation of the value of human capital, reflected in specific indicators, helps to see what the role of various assets in the formation of wealth in modern business entities, how significant investments to the human capital of modern organizations, and what factors determine their growth or decline [3; 4].

The modern concept is considered the human capital precisely as a capital, so it can be counted both in indicators of accumulation, and in indicators of result. The main types of assessment of investment in human capital are costs of education, production training, health protection, improving quality of life, migration, search for information on the labor market, reproduction of the population through fertility and others. In a wide sense, the implementation of all these types of costs contributes to increase the value of human capital, to improve a number of parameters [5; 6]. In a narrow, practical sense, investment to human capital includes, as a rule, the costs of education and training; because these costs mean deliberate process of building the knowledge and skills that are needed to produce a product in a particular field of activity or at specific enterprise. The most of scientific works devoted to evaluation of human capital in enterprise use this narrower interpretation.

Contrary to the existing opinion about fundamental immeasurability of human capital, many modern economists suggest methods to estimate the quantity of human capital in enterprise (or value of human capital). Prof. R. Kapelyushnikov identifies three main approaches (sets of methods) for evaluation of human capital [1]: indicator method, based on various natural characteristics of human capital;cost method, based on the accounting of costs associated with formation, accumulation and development of human capital; income method, based on calculation of incomes received from human capital's use.

\section{RESULTS AND DISCUSSION}

Unlike the scientists investigating the scientific and theoretical approach to the problem, enterprises and organizations wish to have a simple clear methodology for estimating the value of human capital, the parameters which can assess the available potential of labor resources, the effectiveness of their use, etc. The purpose of assessing the value of human capital in any enterprise is to optimize the use of labor resources as one of the most important tasks in management accounting, and at the same time create reserves and receive dividends from highly efficient use of labor resources. The concept of «labor resources» in the micro level of studying human capital is synonymous to definition of «human capital» [7; 8]. The tasks of estimation of human capital's value in enterprise include:

- Calculation of indicators that characterize the size, structure of labor resource, its professional and qualification parameters, its movement, labor productivity, reserve to increase the efficiency of its use;

- Calculation of human capital's cost by using the cost method. Costs of human capital include not just wages, but all expenses that are met the enterprise in developing the labor resource, for example: payment of tuition at universities and training of employees, payment of housing (hostels) for needful workers who do not have own housing, implementation of social programs to help children of employees (paying kindergartens for single mothers and large families), as well as other similar types of expenses. Accounting of these costs in the total amount of expenditures on human capital is a fundamental difference between the calculating the effectiveness of human capital's use and the traditional indicators of labor efficiency (labor productivity and labor intensity), which are usually used in the comprehensive analysis of economic activities [9; 10];

- Calculation of human capital's cost by using the income method. There are many methods of estimating the value of human capital by income, but, unfortunately, there is no uniform method accepted by all specialists. Among the simplest and most convenient for 
practice methods we choose the method offered by Russian scientists - V. Allaverdyan and G.N. Tuguskina [10; 11]. These methods are used to assess the human capital's value of an individual employee; however, we think that the methods can be used for evaluation of human resources value of enterprise as a whole. These methods are fairly simple to use, but they give different results, because they are based on various criteria for estimating the value of human capital, namely, different methods in calculation of the goodwill of human resources potential. follows:

According the method of V. Allaverdyan, the human capital's value is calculated as

$$
\mathrm{S}_{1}=\mathrm{W} \cdot \mathrm{G}_{\mathrm{hp}}
$$

Where: $S_{1}$ is the estimated value of human capital by the method of $\mathrm{V}$. Allaverdyan, $\mathrm{W}$ is the aggregate salary fund of employees, $G_{h p}$ is the goodwill of human resources potential. Goodwill of human resources potentials calculated as $1+$ the share of enterprise in the branch's market, because according to the theory of human capital, image and trust to the company are created by its employees.

According the method of G.N. Tuguskina, the value of human capital is:

$$
\mathrm{S}_{2}=\mathrm{W} \cdot \mathrm{G}_{\mathrm{hp}}+\mathrm{I} \cdot t
$$

Where: $S_{2}$ is the estimated value of human capital by the method of $G$. Tuguskina, $W$ is the aggregate salary fund of employees, $G_{h p}$ is the goodwill of human resources' potential, $I$ is the amount of investment costs for human capital, $t$ is the period of time of investment. The amount of investment in this case will correspond to the amount of investments made in human capital without taking into account wages.

The goodwill of human resources potential in this case is an integral coefficient consisting of three terms:

$$
\mathrm{G}_{\mathrm{hp}}=\mathrm{R}_{\mathrm{hc}}+\mathrm{I}_{\mathrm{hc}}+\mathrm{K}_{\text {prof.pers }}
$$

Where: $R_{\mathrm{hc}}$ is the index of profitability (rentability) of human capital, calculated as the ratio of profit to wages, $I_{\mathrm{hc}}$ is the index of human capital's cost, equal to the share of wage fund in the total amount of expenditure, $\mathrm{K}_{\text {prof.pers. }}$ is the coefficient of professional perspectiveness of personnel in enterprise.

To calculate the coefficient of professional perspectiveness G.N. Tuguskina suggests using the formula recommended by the Russian Labor Research Institute [11]:

$$
\mathrm{K}_{\text {prof.pers. }}=\mathrm{E} \cdot(1+\mathrm{Exp} / 4+\mathrm{Age} / 18)
$$

Where: $E$ is assessment of education level, equal to 0,15 for those employees who have incomplete secondary education; 0,60 - for employees with secondary education; 0,75 - for persons with secondary technical and incomplete higher education; 1,00 - for persons with higher education in the specialty; Exp is the average period of work as the company's employee, Age is the average age of workers in the enterprise.

How applicable are the methods in the actual practice of enterprises? How different are the results of calculating the value of human capital by cost methods and income methods? The authors have tested these methods on the example of one of the Far Eastern foreign trade joint Russian-Chinese enterprises engaged in processing and supplying agricultural products to the Russian market - Primorskaya Agricultural Trade Co., Ltd. The basic data on the personnel potential of this company are presented in table 1.

Table 1 shows that the Primorskaya Agricultural Trade Co., Ltd on the whole, maintains its average number of employees from year to year: by the list number it has decreased only by 5 persons (for 01.01.2017), and by the average number that takes into account the movement of personnel within the calendar year, increased by 7 people, or by $2,7 \%$. This indirectly confirms the relatively positive trends in development of the enterprise itself. 
Table 1- Basic quantitative indicators of human capital in Primorskaya Agricultural Trade Co., Ltd, persons

\begin{tabular}{|l|c|c|c|c|}
\hline \multicolumn{1}{|c|}{ Indicators } & 2016 & 2015 & 2014 & 2016 to 2014 \\
\hline Listed number of employees & 276 & 290 & 281 & -5 \\
\hline Actual number of employees(for 01.01 of each year) & 245 & 262 & 242 & +3 \\
\hline Average annual number of employees & 281 & 276 & 274 & +7 \\
\hline
\end{tabular}

The human capital of enterprise is the actual and potential reserves of labor that the enterprise has at this stage of development. The evaluation of human capital is carried out from the simplest and most well-known indicators that characterize the labor potential of an enterprise, to the unique, complex integral indicators characterizing human capital as such.

Composition, structure, movement and efficiency of human capital, investigated in the framework of the indicator method, are analyzed by traditional methods accepted by modern financial science and practice [12]. Therefore, in this article, we will focus our attention on the newest methods of assessing the value of human capital, namely, accounting the costs and incomes [10; 11].

1. Evaluation of human capital's value by means of the cost method. Based on the data of the Primorskaya Agricultural Trade Co., Ltd, taken from the annual report about the company's financial results for 2014-2016, we calculate the expenses for human capital of this enterprise (table 2).

Table 2 - Costs and efficiency of human capital in Primorskaya Agricultural Trade Co., Ltd, Thousand rubles

\begin{tabular}{|c|c|c|c|c|c|}
\hline Line & Indicators & $\begin{array}{l}\text { Calculation } \\
\text { Procedure }\end{array}$ & 2014 & 2015 & 2016 \\
\hline 1 & Net Revenues from sales & - & 818173 & 924089 & 1000396 \\
\hline 2 & Total net cost of production, including: & - & 759116 & 836991 & 946165 \\
\hline 2.1 & - wage fund, thousand rubles & - & 78275 & 77427 & 80325 \\
\hline 2.2 & - cost for employees' professional training & - & 88 & 135 & 94 \\
\hline 2.3 & $\begin{array}{l}\text { - expenses for reimbursement of cost for employees' training in } \\
\text { institutions of higher education }\end{array}$ & - & 532 & 715 & 806 \\
\hline 2.4 & $\begin{array}{l}\text { - payment of housing in dormitories for workers who do not have } \\
\text { permanent housing in Vladivostok }\end{array}$ & - & 1152 & 1008 & 1008 \\
\hline 2.5 & $\begin{array}{l}\text { - other costs associated with the social security of employees and } \\
\text { satisfaction of their social needs }\end{array}$ & - & 235 & 412 & 306 \\
\hline 3 & Total costs for human capital & $\begin{array}{c}\text { Lines } \\
2.1+2.2+ \\
2.3+2.4+ \\
2.5\end{array}$ & 80283 & 79697 & 82539 \\
\hline 4 & The added value (profit from sales) & - & 59057 & 87098 & 54231 \\
\hline 5 & Profit before taxation & - & 27711 & 27210 & 22250 \\
\hline 6 & Effectiveness of human capital's use, rubles & lines $1 / 3$ & 10,19 & 11,60 & 12,12 \\
\hline 7 & Effectiveness of human capital's use, rubles & lines 2 / 3 & 9,46 & 10,50 & 11,46 \\
\hline 8 & Effectiveness of human capital's use by value added & lines $4 / 3$ & 0,74 & 1,09 & 0,66 \\
\hline 9 & Profitability of human capital & lines $5 / 3$ & $34,5 \%$ & $34,1 \%$ & $27,0 \%$ \\
\hline 10 & The capital intensity of production (in terms of human capital) & lines $3 / 1$ & $9,8 \%$ & $8,6 \%$ & $8,3 \%$ \\
\hline 11 & The share of costs for human capital in the overall cost structure & lines $3 / 2$ & $10,6 \%$ & $9,5 \%$ & $8,7 \%$ \\
\hline
\end{tabular}

As you can from the table 2, the total cost for human capital in the Primorskaya Agricultural Trade Co., Ltd in 2016 amounted to 82.5 million rubles, which is $2.7 \%$ more than just the wage fund, which is used in traditional analysis of efficiency of using labor resources. The cost of human capital is always more than just wages, because it includes the «human», social component that allows forming and developing the professional experience, knowledge and skills of workers (individual human capital). Then these skills and experience are used by the enterprise in production of goods and services, and thereby the human capital of the enterprise is formed and expanded. According to the cost method, 82539 thousand rubles is a value of human capital of the Primorskaya Agricultural Trade Co., Ltd in 2016.

The indicator of effectiveness of human capital's use shows that one ruble of expenditures on human capital brings the enterprise 12,12 rubles proceeds. Over the period 2014-2016, the effectiveness of human capital's use increased by 1,93 rubles, or $19 \%$. We 
can say that $19 \%$ of total increase of the company's income is due to development and increase of the efficiency of human capital's use. Also we can say that one ruble spent on human capital brings the company 11,46 rubles of the value produced, or 0,66 rubles value added. In other words, $21 \%$ of the total increase in the company's value is due to development and increase of the efficiency of human capital's use.

The human capital intensity in the company's production is the indicator that is reverse of the effectiveness of human capital's use. In Primorskaya Agricultural Trade Co., Ltd this indicator decreased from $9,8 \%$ in 2014 to $8,3 \%$ in 2016 . From the point of view of the current development, this indicates an increase in the efficiency of human capital's use, however, from the point of view of strategic development, a systematic reduction of human capital's cost in the total costs of the enterprise indicates a potential reduction in the efficiency of work with personnel, a drop in labor productivity. In future, this may lead to decrease in employee loyalty to the enterprise, to reduction in motivation for increasing labor productivity, to increase in staff turnover, etc. This all could adversely affect the financial position of the enterprise.

The experience of foreign countries shows that only systematic increase of investments in human capital allows to increase competitiveness and improve financial indicators of economic activity. The long-term, or delayed effect of investing in human capital is another fundamental difference between the category of «human capital» and the traditional concept of «labor resources» [13]. Under any unfavorable conditions, Russian enterprises are trying to immediately cut staff costs by cutting staff and saving the money from wages. Foreign large companies, on the contrary, increase investments in human capital by means of qualitative changes in its structure, professional level, etc. Thus they increase the resource base for improving competitiveness under the most difficult market conditions [14].

2. Evaluation of human capital's value by means of the income method of $V$. Allaverdian. The share of Primorskaya Agricultural Trade Co., Ltd on the market is estimated at $10 \%$. According to the formula (1), value of the enterprise's human capital is:

$$
\mathrm{S} 1=80325 \cdot(1+0,1)=88357 \text { thousand rubles }
$$

3. Evaluation of human capital's value by means of the income method of G.N. Tuguskina. We use formulas (2), (3) and (4) to calculate the final value of human capital, the goodwill of human resource potential and the coefficient of professional perspectiveness.

We can calculate the level of education for Primorskaya Agricultural Trade Co., Ltd:

$$
E=(0,6 \cdot 4,2 \%+0,75 \cdot 44,6 \%+1 \cdot 51,2 \%) / 100 \%=0,87
$$

The average length of working in Primorskaya Agricultural Trade Co., Ltd is 10,5 years, the average age of employees is 41,2 years. By means of the formula (4) we calculate Krof.pers.:

$$
K_{\text {prof.pers. }}=0,87 \cdot(1+10,5 / 4+41,2 / 18)=5,14
$$

Then we calculate the goodwill of human resources for the Primorskaya Agricultural Trade Co., Ltd:

$$
\mathrm{G}_{\mathrm{kp}}=0,28+0,085+5,14=5,505
$$

Thus, the value of human capital for the Primorskaya Agricultural Trade Co., Ltd according to the income method of G.N. Tuguskina is equal to:

$$
\mathrm{S} 2=80325 \cdot 5,505+6492=448681 \text { thousand rubles }
$$




\section{CONCLUSION}

If we combine the results of all calculations of human capital's value of Primorskaya Agricultural Trading Co., Ltd in table 3, we can compare the results.

Table 3 - Estimation of human capital's value of the Primorskaya Agricultural Trade Co., Ltd, by means of different methods

\begin{tabular}{|c|c|c|}
\hline Method & $\begin{array}{c}\text { Evaluation } \\
\text { Result }\end{array}$ & Method's Specificity \\
\hline Cost method & 85539 & The total wage fund and all current expenditures on human capital are taken into \\
account
\end{tabular}

As you can see from table 3 , the most significant is the value calculated by the income method of G.N. Tuguskina. This fact tells that the internal potential of the enterprise, based on human capital, is much greater than the external potential, based on current market factors.

The methods used in the process of estimation of human capital's value and listed in table 3 do not exhaust the list of methods for characterizing human capital in any enterprises. However, other methods require deeper data and certain software to process them. Despite the lack of a unified approach to assessing the value of human capital, an enterprise can reasonably choose any of the methods available to date for an objective assessment of the development potential that human capital provides.

\section{REFERENCES}

1. Kapelyushnikov R.I. (2012). How much is the human capital of Russia? Moscow. 76 p.

2. Kasaeva T.V. (2013). Human capital in the industrial and post-industrial age: stock or dynamic process? // Bulletin of the Adyghe State University. №3(127). pp. 21-30.

3. The theory of human capital of enterprise (2012). Edited by A.I. Tatarkin. 400 p.

4. Khudyakova Y.G. (2016). Approaches to the valuation of human capital: the features of use in the conditions of innovative development // Economics and Management: Problems, Solutions. №11. P. 17-20.

5. Danilovskikh T.E., Avakyan A.G. (2015). Methods of assessing human capital: approaches to classification // Fundamental Research. №6-1. pp. 108-111.

6. Innovation potential of national economy: priority directions for implementation: Monograph (2015). Edited by S.S. Chernov. Novosibirsk, Publ. house of the Center for the Development of Scientific Cooperation. $164 \mathrm{p}$.

7. Chernyshov P.A. (2015). Some methodical approaches to the assessment of human capital // Bulletin of the Michurinsky State Agrarian University. №4. pp. 151-155.

8. John Whalley, Xiliang Zhao (2010). The contribution of human capital to China's economic growth. Cambridge: Publ. house National Bureau of Economic Research. $34 \mathrm{p}$.

9. Parkhomchuk M.A. (2011). Methods of assessing the value of the human capital of the organization // Bulletin of the Kursk State Agricultural Academy. №6. pp. 45-46.

10. Kolomytseva O.Yu., Chekudaev K.V., Chekudaeva I.A., Druchinina A.V. (2016). Methods for assessing the intellectual capital of an enterprise as a factor of production // Vestnik Voronezh State University of Engineering Technology. №4(70). pp. 280-283.

11. Tuguskina G.N. (2011). Development of a methodology for assessing human capital in the value of an enterprise // Vestnik of University. №6. pp. 174-177.

12. Sheremet A.D. (2015). Complex analysis of economic activity: the textbook for university students. M.: Publ. house INFRA-M. 255 p.

13. Asaliev A.M. (2014). Labor Economics: Textbook. M.: Publ. house INFRA-M. 171 p.

14. Vorozhbit O.Y. (2010). The structure of the business environment: determining factors // Bulletin of the Pacific State University. №4. pp. 121-128. 